\title{
В.И. Пинковский
}

\section{ВÉRÉZINA В РЯДУ ПОЛНЫХ СИНОНИМОВ - ИМЕН СОБСТВЕННЫХ СО ЗНАЧЕНИЕМ «КАТАСТРОФИЧЕСКАЯ НЕУДАЧА»: ЛИНГВИСТИЧЕСКИЙ И КУЛЬТУРОЛОГИЧЕСКИЙ АСПЕКТЫ}

\begin{abstract}
Исследуется группа франиузских прецедентных онимов со значением «катастрофическая неудача» и ставится вопрос о феномене слова Ве́ге́zina - более частом, в сравнении с другими членами синонимического ряда, использовании его в разных областях культуры. Автор приходит к выводу, что причины возникновения указанного явления кроются в образной природе и поле интерпретации синонимичных концептовонимов. В частности, Ве́rézina порождает в коллективном сознании носителей франиузского языка непосредственные физические (телесные) ошущения, что, вероятно, приводит к более сильному переживанию события, а также стыкуется с массовыми представлениями (мифы, предрассудки) о России.

Ключевые слова: Bérézina; Waterloo; Leipzig; Sedan; абсолютно синонимичные онимы; доминирующее слово синонимического ряда; концепт; образы, убеждения и предрассудки национального сознания.
\end{abstract}

\section{Введение}

В настоящей работе рассматриваются синонимы - имена собственные, ставшие, благодаря приобретению метонимического значения, полными синонимами. Само это явление, даже в его наиболее общем виде, нечасто становится объектом филологического рассмотрения. Исследователи указывают на то, что «для проприальной лексики не свойственна синонимия в привычном понимании... для нее характерна ономастическая синонимия» [1], но имеют в виду, как правило, имена собственные в первичном значении, в то время как, наполненные коннотативной семантикой, они представляют собой, видимо, особый класс слов, сочетающих черты онимов и апеллятивов, чем и объясняется тяготение этих лексем к приобретению графических и морфологических свойств последних (написание со строчной буквы, образование множественного числа и, если это позволяет грамматический строй конкретного языка, падежных форм).

В работах ономастической тематики нередко используются примеры с синонимичными прецедентными именами собственными [2. С. 69, 76, 90, 99,$110 ; 3$. С. 53-90], но объектом научной рефлексии в аспекте полной синонимии, за редким исключением [4. С. 68-70; 5. С. 68], эти онимы не становятся. А между тем преимущественное использование одного из них не только свидетельствует о неких общечеловеческих представлениях, но и обнажает этнокультурные особенности носителей языка (предпочтения, убеждения, предрассудки, мифы) в конкретную историческую эпоху. 
Цель статьи - определить, почему слово Bérézina, входящее в довольно протяженный ряд онимических синонимов, объединенных архисемой «катастрофическая неудача», заняло в речи исключительное положение по частотности и разнообразию использования ${ }^{1}$. Работа выполнена в рамках интерпретационного подхода, предваренного функционально направленным лингвистическим анализом словесного материала в нескольких аспектах от артикуляционно-фонического до семантического. Материалом для наблюдения и оперирования послужили словарные дефиниции лексикографических и иных справочников, а также публицистические, мемуарные, документальные и художественные тексты XIX-XXI вв. на французском языке (всего - около 400).

\section{Bérézina во французской и русской лексикографии}

В современных французских словарях Bérézina рассматривается как разговорное слово со значением «разгром, крах, урон» (désastre, perte) [6. P. 38], синонимичное, кроме того, таким лексемам, как catastrophe (катастрофа, гибель), échec (провал), malheur (несчастье), calamité (бедствие, несчастье, катастрофа), fléau (бич, бедствие), cataclysme (стихийное бедствие, потрясение), accident (несчастный случай), crise (кризис), bouleversement (потрясение, разрушение), misère (неудача, невзгода) [7]. Примечательно, что даже в историческом словаре в статье о сражении на Березине автор счел необходимым упомянуть, что «...этот трагический эпизод оставил след в разговорном языке, сделавшись синонимом катастрофы» [8. Р. 80]. Однако наиболее распространенным обозначением крупной неудачи Bérézina, похоже, стала только в XX в. В предшествующем столетии это место занято другим онимом - Waterloo. По крайней меpe, в «Аналогическом словаре французского языка» П. Буасьера, в статье VAINCU (побежденный), упоминается именно последнее сражение Наполеона I, а Bérézina вообще отсутствует [9. Р. 1375].

Российский лексикон приводит оба слова, но с оттенками значения: «Березина - катастрофа, провал, неудача, невезение»; «Ватерлоо - полный провал, крах» [10. С. 64, 629]. В исследованиях российских филологов предпринимаются попытки подтвердить обозначенные в словаре различия. Направленность этих усилий определяется в основном одной из двух исходных позиций - рационалистической, когда во внимание принимается разная историческая значимость событий [11. С. 74-83], или психологической, обусловленной эмоциональным впечатлением: «Березина... предполагает некую надежду выхода из... безнадежной ситуации. <..> Ватерлоо же - это символ утраты всякой надежды» [12. С. 218]. Оба представленных подхода закономерны, однако могут быть успешны только при совместном применении и учете всего синонимического ряда, в который входят лексемы.

\footnotetext{
${ }^{1}$ В статье встречаются две формы написания онима: Bérésina / Bérézina - вынужденное отражение неунифицированной орфографии слова в цитируемых текстах. В современных словарях, в том числе российских, утвержден вариант Bérézina
} 


\section{Bérézina и Waterloo в синонимическом ряду}

Группа топонимов, связанных с большими военными неудачами французов в разные эпохи, достаточно велика: Cresy (1346 г.), Poitiers (1356 г.), Azincourt (1415 г.), Pavie (1525 г.), Rossbach (1757 г.), Bérézina (1812 г.), Leipzig (1813 г.), Waterloo (1815 г.), Sedan (1870 г.) и др. Хотя все эти метонимии используются вплоть до настоящего времени (см., например, в тексте 1975 г.: ...un Sedan intellectuel, un Rossbach artistique, un Azincourt philosophique [13. Р. 123]), наиболее актуальными являются последние четыре. Их тесная связь в национальном сознании подтверждается множеством источников XIX в. В анонимном тексте 1814 г. представлены еще только два первых топонима: ...pавнины под Лейпиигом тотчас же напоминают берега Березины ... [14. Р. 14-15], а в изданиях последней трети столетия вразбивку или даже полностью указывается уже весь «квартет» [15. Р. 19]. Так образовалась номинативная избыточность в экспрессивно-образном обозначении катастрофической неудачи.

Как известно, увеличение количества членов синонимического ряда сопровождается дифференциацией значений между ними. Однако использование всех четырех слов совершенно очевидно регламентируется на протяжении XIX и начала XX в. не стилистическими нормами, или оттенками смысла, или обстоятельствами описываемой ситуации, а личными пристрастиями и привычками говорящих. О дипломатическом провале можно было сказать un Leipzig diplomatique [16. Р. 159], а можно и un Waterloo diplomatique [17. Р. 46]; крупная политическая неудача удостаивалась наименования la Bérésina politique [18. Р. 6], но не было препятствий назвать ее и ce Sedan politique [19. Р. 471]. Полнее всего возможность одного из онимов (а значит, и всех остальных) сочетаться с разными определениями продемонстрировал в своем романе «Беспочвенники» (1897 г.) М. Баррес: ...nous n'avons pas subi seulement un Sedan militaire, politique, financier, industriel; c'est encore un Sedan intellectuel [20. P. 321].

Мы можем констатировать, что в сфере социального дискурса все четыре слова выступают как полные синонимы - для обозначения крупной неудачи в политике, спорте, в области культуры и т.д. Однако равные семантические возможности слов еще не обеспечивают одинаковой частотности их употребления. В XIX в. реже всего используется Leipzig, чаще всего - Waterloo, в XX - на первый план выдвигаются Bérésina и Waterloo: La Bérésina des républicains du Congrès (Березина республиканцев в Конгрессе) [21], Un «Waterloo» de la responsabilité politique («Ватерлоо» политической ответственности) [22].

Очевидно, что причины выдвижения в XX столетии на первый план двух названных лексем и меньшая востребованность двух других взаимосвязаны. 


\section{«Конкуренция» внутри синонимического ряда: логико-лингвистический аспект}

Специфику исследуемого синонимического ряда позволяют определить выявленные А.В. Лемовым [23. С. 211-213] факторы сохранения в языке абсолютных синонимов «нетерминологического характера». Мы применим классификацию, предложенную этим исследователем, к нашему материалу.

А) Выбор слова с более понятной внутренней формой. В нашем случае такой выбор неосуществим, потому что обе доминирующие лексемы не являются французскими, кроме того, этимология топонима не имеет отношения к событию, связанному с ним.

Б) Артикуляционно-акустическое преимущество одного из сочленов. Колебания в написании свидетельствуют о том, что наименее удобным для произношения и восприятия на слух французам казалось название немецкого города: Leipsick / Leipzig. (См. для сравнения расхождения в графическом облике Waterloo, не влияющие на звучание слова: Waterlot / Waterlo. То же относится и к отмеченному выше чередованию Bérésina / Bérézina: оба варианта произносятся одинаково.) Казалось бы, все преимущества в этом аспекте принадлежат французскому ониму Sedan. Однако, кроме логической мотивировки выбора слова, есть и другие. В одном из текстов 90-х гг. ХІХ в. мы встречаем психологические основания возможного предпочтения слова по его артикуляционно-фоническим качествам: Ватерлоо! Эти три слога заключают в себе бесповоротный смысл многих судеб. Отныне в воображении они соединены с особенной формой - двойнылм «в» и удвоенным «о»... Ватерлоо, - повторил он, заставляя мрачные созвучия слова причудливо воздействовать на слух... [24. Р. 154]. Обращаясь к подобным материалам, следует, конечно, учитывать тенденции, распространенные в художественной литературе конкретной эпохи. Конец XIX столетия - поздняя фаза символизма, а это направление уделяло особое внимание звучанию слова, причудливым выражением чего явилась, например, теория Р. Гиля (1886 г.), предлагавшего ассоциировать звуки и их сочетания с определенными музыкальными инструментами [25. T. 3. Р. 195-252], или более поздняя - «чистой поэзии» - аббата Бремона (1926 г.), который призывал к победе «поэзии над разумом», т.е. к суггестивному внушению неких эмоций и смыслов фоническими средствами в обход значения слов [26. Р. 18-19]. В любом случае, субъективная семантизация звуков не образует закономерности, поэтому невозможно причислить ее к факторам коллективного предпочтения того или иного слова.

В) Ограничения в валентности (сочетаемости, окружении). Как показывают приведенные выше примеры использования слов, этот фактор не является дифференцирующим для членов данного синонимического ряда.

Г) Различная словообразовательная активность и словообразовательная функция дублетов. Относительное преимущество в этом аспекте имеют как раз недоминантные элементы ряда, от которых образуются относительные прилагательные, в том числе субстантивированные: Leipzig - 
leipzigois, Leipzigois; Sedan - sedanais, Sedanais [27. P. 1603, 1608]. Bérézina и Waterloo образуют аналогичные значения при помощи предложных конструкций с de. Следует заметить, что и те и другие производные имеют отношение к прямому, т.е. топонимическому, значению синонимов, в то время как метонимии дериватов не имеют.

Д) Различная реализация возможности метафорических и других семантических переносов. Способностью образовывать метафорические значения, как мы покажем далее, обладает только Bérézina, однако предстоит выяснить, каким образом метафорический потенциал слова создал ему преимущественное положение среди других членов синонимической группы.

Проведенная проверка позволяет сделать следующий вывод: в синонимическом ряду, состоящем из онимов-метонимий, представляющих собой, кроме того, полные синонимы, отношения между элементами (выдвижение в наиболее используемую группу, пребывание в пассивной зоне, вытеснение из ряда) объясняются факторами не логическими и сугубо лингвистическими, а теми, что принадлежат концептосфере.

\section{«Конкуренция» внутри синонимического ряда: концептный аспект}

Согласно поздней (2005 г.) дефиниции Ю.С. Степанова, «конщепт можно определить как понятие, но расширенное ситуацией» [28. С. 344]. Под ситуацией логично понимать не только условия формирования концепта, но и обстоятельства его понимания (т.е. интерпретации) и использования. Очень важно, какой силы чувственный образ несет в себе концепт, какие ассоциации он вызовет в воспринимающем сознании. Если такой образ не отличается выразительностью, то связанный с ним концепт оказывается в проигрышном положении.

Именно этой причиной, судя по всему, объясняется уход из активного употребления слова Leipzig. Действительно, крупнейшее из всех сражений Наполеона I не отмечено каким-нибудь ярким эпизодом, который мог бы претендовать на статус легендарного, возникать в воображении при упоминании о «Битве народов», не увековечено отточенной фразой, произнесенной кем-либо из участников события, не врезалось в коллективную память ничем, что отличало бы это крупное поражение от подобных ему. Для современников битвы и в некоторой степени для двух последующих поколений память о Лейпцигской битве была актуальной, но уже к концу XIX в. Leipzig в значении «военная катастрофа» практически не встречается во французских текстах. (Следует также принять во внимание, что с названием немецкого города на протяжении столетий и по сей день ассоциируется такое ежегодное мероприятие, как Лейпцигская ярмарка (la foire de Leipzig), что делает невозможным однозначное употребление слова.)

Причина нечастого использования слова Sedan, видимо, является сугубо психологической. По логическим причинам это слово для обозначения тяжелейшего поражения должно было бы оттеснить все остальные (в плен 
попало более 70 тыс. французов во главе с Наполеоном III), но сквозь его основное метонимическое значение проступает еще одно - позор. Это «поражение постыдное», désastre honteux de Sedan [29. Р. 5]: Лейпциг, Baтерлоо - это дни славы (des jours de gloire) по сравнению с Седаном [30. P. 70]; Седан - более ужасное имя, чем эти проклятые имена (сеs потs maudits) Лейпциг и Ватерлоо [31. Р. 163].

Разумеется, речь идет о понимании события в коллективном сознании, поскольку существуют как минимум три позиции в отношении «неприятного» исторического факта. Объективный взгляд представляет (в идеале) историческая наука. Часто встречающаяся позиция власти, заботящейся о репутации и внутренней устойчивости государства, - смягчающе-возвышающая. Наконец, существует реакция народная, не только наивная и мифологизированная, но и самая бескорыстная, ибо ее непосредственность лишена расчета двух первых позиций (на предъявление $u c m u н ь$, на поддержание реноме и прочее). Безотчетность неподдельного переживания придает массовому восприятию произошедшего статус высшей убедительности.

О непохожей трактовке Седана в разных слоях общества писал через несколько лет после битвы Ж. Делафос: «Что означает имя Седан в расхожем (vulgaire) восприятии? Концентрированный невыразимый стыд (une accumulation de hontes inexprimables)... А что такое Седан в глазах историков? Гигантская катастрофа, к упоминанию о которой ни в малейшей степени не примешивается чувство стыда, а те немногие, что принимают ее близко к сердцу, склонны видеть лишь великую жертву (un grand sacrifice)...» [32. Р. 25]. Можно предположить, что в массовом сознании употребление онима Sedan в значении «крупная неудача» блокируется неприятными ассоциациями.

Совсем другое дело - Waterloo. Ф. Жербе восклицает: «Мы были побеждены под Ватерлоо, но не без славы!» [33. Р. 4]. (Ср. название книги современного историка, также утверждающее идею поражения, овеянного славой: «Napoléon et Waterloo: la défaite glorieuse de 1815 à nos jours» [34].) Следует различать аналитическое осознание исторического события и его образ. Судя по многим признакам, образ сражения в массовом сознании современников строился по законам эпоса (не рода литературы, а жанра). В первую очередь это проявляется в том, что событие мыслится не как звено в каузальной исторической цепи, а как результат действия неких вечных сил. Эта черта воплотилась в трактовке битвы В. Гюго, который совместил античную идею судьбы и христианскую - «божьей воли»: Громадная тень деснищы божией простирается над Ватерлоо. Это день свершения судьбы [35. Р. 55]. Мнение В. Гюго авторитетное, но позднее (1862 г.), к тому же известно присущее писателю тяготение к грандиозному. Однако оно соответствует в данном случае духу эпохи, в которую формировалось представление о сражении. К. Делавинь, обязанный своей литературной славой поздней Империи и ранней Реставрации, первую (1815 г.) из своих знаменитых «мессенских элегий» посвящает именно Ватерлоо и называет павших в битве воителями, преданныли судьбой (cеs 
guerriers par le destin trahis) [36. Р. 6]. О популярности такого объяснения катастрофы среди современников поэта свидетельствует фантастическое количество проданных текстов - 21000 экземпляров (обычный тираж поэтической книги в эту эпоху - от 500 до 2000 экз.). Читатели были подготовлены к такому отклику на идеи элегии имперской идеологией, для которой осмысление исторических событий в провиденциальном ключе было весьма характерно, что повлияло и на восприятие Waterloo.

Типичной чертой эпоса является гиперболизм в широком смысле (в изображении масштаба события, меры проявленных участниками качеств, в патетичности стиля). Ограничимся двумя примерами его проявления. В одной из французских пьес сороковых годов (время нарастания повторного культа Наполеона I) сын наполеоновского ветерана убежденно говорит: Под Ватерлоо один старый гвардеец бился против десяти союзников [37. P. 7]. Аббат Дежарден в посвященной героям Ватерлоо оде напрямую сравнивает их с рыцарями графа Роланда, количественно в разы уступавшими войску мавров и столь же превосходившими врага доблестью [38. Р. 3].

В эпосе необходимо наличие персонажа, воплощающего национальный героический идеал. По стечению обстоятельств в этой почетной роли оказался генерал П. Камбронн, «граф Роланд» Ватерлоо, а возглавляемые им солдаты гвардии стали «роландовыми рыцарями». Приписываемая генералу фраза (La Garde meurt et ne se rend pas - Гвардия умирает, но не сдаетcя), произнесенная в ответ на предложение англичан о сдаче, вызывала и вызывает скепсис у сторонников реалистического взгляда на вещи («Хорошая сцена для оперы. С трудом представляю ее на батальном поле» [39. P. 32]), но эпическому витязю она совершенно необходима для завершения его образа. Даже добавленное героем к этой фразе бранное слово merde! (дерьмо) не умаляет трагического величия финального эпизода битвы, потому что брань - в духе «ворчунов» (grognards - солдаты Старой императорской гвардии). И вот этому слову посвящает строки в приподнятом тоне В. Гюго в «Отверженных», о знаменитом ругательстве слагаются стихи, в которых, правда, оно не называется, но легко восстанавливается подбором рифмы к se perde: Que ce grand souvenir non jamais ne se perde! // Ils allaient tous mourir!.. Cambrone cria... [40. Р. 28]. П. Камбронн, по справедливому утверждению одного из его биографов, живет в народном воображении в качестве «персонажа», воплощающего национальный темперамент и символизирующего «героизм... священной когорты» сражавшихся при Ватерлоо [41. Р. 234].

Представляя битву при Ватерлоо как определенное действо, следует помнить, что эстетические вкусы, культивируемые в Первой империи, являются классицистическими (на сцене идут трагедии П. Корнеля и его имперских эпигонов, сам Наполеон - поклонник знаменитого драматурга), а в театре классицизма афористически отточенная речь является не только носителем смысла, но и системой словесных жестов, компенсирующих сравнительную бедность внешнего действия и оживляющих в сознании тот или иной стандартный образ (поза героя, выражение лица и прочее). Эпи- 
зод с прославленной фразой Камбронна вписывается в эту систему, на эпическое основание накладывается привычная современникам ампирная трагедийная величавость.

Закрепленность образа Waterloo в коллективном сознании, амбивалентность восприятия и переживания этого исторического события, которое Л. Бельмонте удачно определил как славу, пронизанную печалью [42. P. 143], обеспечило слову преимущество в использовании перед такими лексемами, как Leipzig и Sedan.

Bérézina стоит особняком среди остальных членов синонимического ряда - не столько по масштабу события, не сравнимого с крупными сражениями XIX в., сколько по специфике его восприятия, в котором три обозначенные выше позиции различаются не оттенками, а полной смысловой разнонаправленностью. Власть, в первую очередь в лице самого Наполеона, просто умалчивает о катастрофе, упоминаний о которой нет в письмах императора, отправленных непосредственно после Березины, что объясняется желанием «доставлять парижанам только хорошие новости», внушающие оптимизм [43. Р. 20]. Но и в продиктованных на острове Святой Елены мемуарах о самой переправе сказано буквально в одной фразе: «Армия, завершив переход через Березину, разрушила мосты и продолжила свой марш на Вильну...» [44. Р. 334], основное же внимание уделено предварительным, отвлекающим внимание русских войск действиям.

Историки, оценивая маневры Наполеона, сбившие с толку его русских визави П.В. Чичагова и П.Х. Витгенштейна, обоснованно, хотя и с неуместным пафосом восхваления, пишут, что французский император «вышел победителем из ситуации, которая... казалась безнадежной» [45. Р. 36] и даже что вся Березинская операция была «блистательным и героическим военным успехом» [46. Р. 538]. Цельная и взвешенная историческая оценка принадлежит Л.Н. Толстому. Писатель, не преувеличивая значение события, отказывая катастрофической переправе в статусе «решительного эпизода кампании», дает обобщающее объяснение тому эффекту, который произвела $B e ́-$ résina: «...на Березинском прорванном мосту бедствия, претерпеваемые французской армией прежде равномерно, здесь вдруг сгруппировались в один момент и в одно трагическое зрелище, которое у всех осталось в памяти» [47. С. 211]. Что именно осталось в коллективной памяти?

Народное отношение к Березинской переправе сформировалось в обход официального, и оно не менее избирательно: ни ловким тактическим приемам военачальников, ни собственно боевым эпизодам на обоих берегах реки в нем не нашлось места. В мемуарах участников злосчастного перехода есть картины давки перед мостами и на них, есть сцены гибели наиболее слабых и беспомощных (раненых, а также многочисленных некомбаттантов - французов, бежавших с армией из России), описание обстрела переправы русской артиллерией, но в качестве наиболее заметного смертоносного фактора выделен холод, упоминание о котором является единственной чертой, объединяющей и пропагандистские, и историографические, и мемуарные, и художественные источники. 
Действительно, какие детали чаще всего встречаются в повествованиях о Березине? Обледенелые берега (les rives glacées), заледеневшая почва (les gazons glacés), ледяные волны (les flots glacés), льды (les glaces de la Bérésina), снега (les neiges de la Bérésina). Реку называют Ахероном для франиузов [48. Р. 47], ледяной могилой [49. Р. 226]. Т. Готье, описывая ветеранов Старой гвардии, акцентирует внимание на двух чертах в их облике - npunудренных снегами России волосах и дрожащих от холода Березины руках [50. Р. 85-86]. Несмотря на то, что большинство погибших при переправе утонули, это обстоятельство не перевешивает ужаса перед холодом. Встречающееся в некоторых текстах сравнение Березинской переправы с Нантскими утоплениями (печально известные казни на Луаре во время Французской революции) не привело к распространению названия Березинское утопление (la noyade de la Bérésina [51. Р. 113]). Это «предпочтение», оказанное холоду, совсем не случайно, в нем нашли отражение как общечеловеческие чувственные впечатления, так и сугубо национальные предрассудки. Начнем с последних.

Е.-М. де Вогюэ, известный историк литературы, проживший в России несколько лет, признавался, что для большинства его соотечественников Россия - это «казак, восседающий на глыбе льда» [52. Р. 14]. Для многих участников похода в Россию суровый климат стал психологическим оправданием поражения, в их мемуарах часто встречается утверждение, что Наполеона победил не Кутузов, а «генерал мороз» (le général moroze) [53. Р. 128]. Это расхожее мнение проникает и в художественную литературу. Бонапартистски настроенный молодой Ж. де Нерваль пишет: «О русские... ваш климат скоро отомстит за нанесенные вам обиды. Рассудите: тот, кто побеждал людей, не властен над природой!» [54. Р. 28]. В контексте таких представлений Bérézina косвенно возводится в ранг природных катаклизмов, проигрыш в противостоянии с которыми трагичен, однако не постыден для человека.

Уникальная черта событий на Березине: их героями стали не те, кто стреляет, атакует или обороняется, а саперы, возводившие два спасительных моста. Эти самоотверженные солдаты, в большинстве погибшие, пострадали не от пуль, ядер и штыков, а от пребывания в холодной воде. Можно умозрительно, по шаблонам представлений о битвах вообще, вообразить эмблематически эффектные эпизоды других сражений (последний бой Гвардии при Ватерлоо), но Березинская трагедия ощутима, кроме прочего, особенным образом - телесно. Именно это обстоятельство, как нам представляется, оказало решающее влияние на судьбу слова Bérézina, потому что телесность овеществляет отвлеченное понятие, а кроме того, делает его близким, непосредственно ощутимым и неизбежно способствует его амбивалентной трактовке - возвышенной и грубовато-сниженной, комически-фамильярной.

Об этом свидетельствуют многочисленные тексты XIX в. В романе Э. Ришбура есть персонаж по прозвищу le père Bérésina (nanama Березина), один из тех, кто чуть не погиб в ледяной воде этой русской реки. 
Немаловажно признание героя в том, что он никогда не был женат и не мог иметь детей [55. Р. 94]. Образ старика трогателен, нравственно возвышен, но прозвище, данное ему в молодости, с грубоватым комизмом намекает на физические последствия пребывания в водах Березины. Эту же функцию выполняет такая деталь внешности cmapblx вояк (les vieux braves), как нос, отмороженный на Березине (le nez gelé à la Bérésina) [56. P. 284; 57. Р. 131]. В женских персонажах, носящих прозвище Bérésina, отмечается ситуативная безэмоциональность [58. Р. 58] или холодный нрав в целом [59. Р. 275].

Трагикомической метафоризацией возможности слова не исчерпываются. Оно может означать некое телесное неудобство вообще, например дискомфорт в глазах: Sa Bérésina, ce fut les... éraillements de ses yeux [60. P. 162], дрожь от холода: Brrr!.. Quelle Bérésina..! [61. Р. 344] и т.д. Наконец, выходя из круга телесных ощущений, Bérésina актуализирует иные элементы своей семантики, выражая различные психические состояния, как правило связанные с неприятными ситуациями повседневной жизни. Так, Л. де Сиври, описывая ливень в Риме, называет уличные потоки cette Bérésina d'une nouvelle espèce (эта в некотором роде новая Березина), а чувство беспокойства, вызванное буйством вод, усилено крушением тротуарного дощатого настила, напомнившего мосты через Березину [62. Р. 361]. Еще пример (повествователь в отягощающем предчувствии неких неудач): Je sais de science certaine que le mars de 1986 sera marqué... par des revers, mais qui ne seront pas waterlos: tout juste de petites bérésinas [63. Р. 35] (Я знаю определенно, что март 1986 года будет отмечен неудачами - не ватерлоо, но мелкими березинами). В приведенной фразе очень показательно проявляющееся именно в бытовом узусе противопоставление апеллятизированных Waterloo и Bérésina: первое слово тяготеет к обозначению крупных неудач, второе - текущих неурядиц, в том числе их ожидания и переживания. Широкое использование метафорических значений Березины в бытовой сфере позволило слову занять прочное место в разговорном слое французской лексики, благодаря чему и в синонимическом ряду «катастрофическая неудача» оно более востребовано, чем другие члены ряда.

\section{Выводы}

Отвлекаясь от деталей эмпирической конкретики, связанной со словом Bérésina, можно прийти к следующим обобщениям.

В ряду, состоящем из полных синонимов - имен собственных, наиболее часто и разнообразно используются слова:

а) обладающие большим образным потенциалом;

б) не «конфликтующие» с ментальными стереотипами национального сознания;

в) не вызывающие недопустимо травмирующих психику ассоциаций;

г) допускающие употребление в личной и бытовой сфере, поскольку явления, наполняющие эту область, разнообразны и многократно повторяются, что позволяет непрерывно актуализировать арсенал значений слова и добавлять к ним новые оттенки. 


\section{Литература}

1. Скляренко O.Н. О лексико-семантических особенностях собственных имен. URL: http://dspace.onu.edu.ua:8080/bitstream/123456789/4559/1/170-181.pdf

2. Нахимова E.A. Прецедентные онимы в современной российской массовой коммуникации: теория и методика когнитивно-дискурсивного исследования. Екатеринбург : Урал. гос. пед. ун-т, 2011. $276 \mathrm{c.}$

3. Мерзлякова А.B. Семантический потенциал топонимов современного французского языка : дис. ... канд. филол. наук. Н. Новгород, 2015. 19 с.

4. Кудрявиева A.A. Особенности сочетаемости мифонимов, перешедших в имена нарицательные // Ученые записки Забайкальского государственного гуманитарнопедагогического университета им. Н. Г. Чернышевского. 2011. № 2 (37). С. 67-70.

5. Кудрявцева A.A. Основные типы онимов, способных переходить в имена нарицательные // Известия Волгоградского государственного педагогического университета. 2013. № 4 (79). C. 65-68.

6. Caradec F., Pouy J.-B. Dictionnaire de Français argotique et populaire. Paris : Larousse, 2009. $366 \mathrm{p}$.

7. Reverso: dictionnaire. URL: http://dictionnaire.reverso.net/francais-definition/beresina

8. Dictionnaire de l'histoire de France / sous la direction de J.-F. Sirinelli. Paris : Larousse, 2006. $1176 \mathrm{p}$.

9. Boissière $P$. Dictionnaire analogique de la langue française: répertoire complet des mots par les idées et les idées par les mots. Paris : A. Boyer, 1862. 1439 p.

10. Гринева Е.Ф., Громова Т.Н. Словарь разговорной лексики французского языка. М. : Цитадель, 1997. 640 с.

11. Шумакова А.Н. Об особенностях использования лексики с культурным компонентом в современной прессе (на материале топонимов, связанных с некоторыми военными кампаниями Наполеона) // Вестник Московского государственного лингвистического университета. 2015. № 9 (720). С. 74-83.

12. Постникова A.A. Прецеденты Наполеоновской эпохи в коммуникативной памяти современной Франции: от «Аустерлица» до «бистро» // Политическая лингвистика. 2014. № 3 (49). C. 216-223.

13. Caraco A. Ma confession. Lausanne : L'age d'homme, $1975.260 \mathrm{p}$.

14. L'agonie d'un sénateur, et son amende honorable à la nation française. Paris : Chez les marchands de nouveautés, $1814.16 \mathrm{p}$.

15. Berthezène A. Waterloo. Paris : E. Leroux, 1892. 20 p.

16. Chambrun J.-D.-A.-P. Fragments politiques. Paris : Garnier frères, 1872. $446 \mathrm{p}$.

17. Déchalotte J.-B. La France et l'Angleterre d'autrefois et d'aujourd'hui. Paris : Blot, 1858. $47 \mathrm{p}$.

18. Mague A. Dédicace à Madame la Duchesse d'Uzès. Le Proscrit de Jersey. État actuel de la France, impression de cet état en Europe. Paris : Charles, 1890. 24 p.

19. Teste L. Anatomie de la République (1870-1910). Paris : Librairie du XX-e siècle, 1910. $485 \mathrm{p}$.

20. Barrès M. Le roman de l'énergie national. Les déracinés. Paris : E. Fasquelle, 1897. $493 \mathrm{p}$.

21. Bussard $S$. La Bérésina des républicains du Congrès. URL: https://blogs.letemps.ch/ etats-unis/2015/03/04/la-beresina-des-republicains-du-congres/

22. Neumann L. Un «Waterloo» de la responsabilité politique. URL: http://www.lepoint.fr/invites-du-point/laurent-neumann/neumann-un-waterloo-de-laresponsabilite-politique-13-06-2015-1936119_2449.php

23. Лемов А.В. Тождественны ли дублеты-синонимы? // Историческая и социальнообразовательная мысль. 2015. Т. 7, № 3. С. 211-213.

24. Hervieu P. L'armature. Paris : A. Lemerre, 1895. 325 p. 
25. Ghil R. En méthode à l'œuvre // Ghil R. Cuvres complètes. Paris : A. Messein, 1938. T. 3. P. $195-252$.

26. Bremond H. La poésie pure. Paris : B. Grasset, 1926. 321 p.

27. Le Robert pratique: dictionnaire d'apprentissage de la langue française. Paris: Le Robert, 2011. $1611 \mathrm{p}$.

28. Степанов Ю.С. Французская стилистика (в сравнении с русской). М. : Книжный дом «Либроком», 2013. $360 \mathrm{c}$.

29. Hubbard G.-A. Le budget des 3 monarchies et le budget de la République. Paris : Société d'instruction républicaine, $1873.40 \mathrm{p}$.

30. Le dernier Empire. Paris : E. Dentu, 1875. 72 p.

31. Bigot Ch. Le petit Français. P. : E. Weill et G. Maurice, 1883. 204 p.

32. Delafosse J. Le procès du 4 septembre. Paris E. Lachaud et Cie, 1876. 71 p.

33. Gerbet $P h$. Un mot sur les catastrophes des armées françaises en 1870-1871. Arbois : Javel, 1871. $10 \mathrm{p}$.

34. Largeaud J.-M. Napoléon et Waterloo: la défaite glorieuse de 1815 à nos jours. Paris : Boutique de l'histoire, 2006. $462 \mathrm{p}$.

35. Hugo V. Les misérables: 5 vol. 2-e partie. Cosette. Paris : Hachette, 1881. 416 p.

36. Delavigne C. Première Messénienne, sur la bataille de Waterloo // Delavigne C. Trois Messéniennes, élégies sur les malheurs de la France. Paris : Ladvocat, 1818. P. 5-11.

37. Clairville. Le retour de Sainte-Hélène: à-propos national en un acte. Paris : Tresse, 1840. 8 p.

38. Desjardins, abbé. Roncevaux. Gloire aux vaincus! Melun : A. Hérisé, 1866. 3 p.

39. Houssaye $H$. La garde meurt et ne se rend pas: histoire d'un mot historique. Paris : Perrin, 1907. $61 \mathrm{p}$.

40. Fontaubert, É. de. Le mot de Waterloo // Fontaubert, É. de. Chants et chansons de Pourceaugnac II. Limoges: Vve H. Ducourtieux, 1869. P. 27-28.

41. Sérieyx $W$. Cambronne. Paris : J. Tallandier, 1931. 253 p.

42. Belmontet L. Waterloo // Belmontet L. Poésie de l'Empire français. Paris : Impr. impériale, 1853. P. 139-144.

43. Cain J., François M. Exposition des 318 lettres de Napoléon à Marie-Louise récemment acquises par le Gouvernement français. Paris : Bibliothèque national, 1935. $47 \mathrm{p}$.

44. Napoléon I. Mémoires de Napoléon, écrits sous sa dictée à Sainte-Hélène, par un de ses valets de chambre. Paris : Philippe, 1829. $428 \mathrm{p}$.

45. Pierron É. Comment s'est formé le génie militaire de Napoléon I? Paris : L. Baudoin, 1889. 39 p.

46. Zamoyski A. 1812: Napoleons Feldzug in Russland. München : C.H. Beck, 2012. 720 S.

47. Толстой Л.Н. Война и мир // Собр. соч. : 12 т. М., 1984. Т. 6.544 с.

48. Neuville A. Bérésina // Neuville A. Euvres d'un désœuvré. Chaumont : Mion, 1837. P. 47.

49. Delandine de Saint-Esprit J. Histoire de l'Empire, 1804-1814. Paris : Mallet et Cie, $1843.544 \mathrm{p}$.

50. Gautier Th. Vieux de la Vieille// Gautier Th. Émaux et camées. Paris : G. Crès et Cie, 1913. P. 81-87.

51. Puech L. Le despote: abrégé historique du règne de Napoléon I. Castres : A. Fraysse, 1877. $187 \mathrm{p}$.

52. Vogüe E.-M. de. Discours // Banquet franco-russe du 26 octobre 1893. Paris : Colin, 1893. P. $14-15$.

53. Les prisonniers français en Russie (1813-1814). (S. 1.), 1859. 240 p.

54. Nerval G. de. La Russie // Nerval G. de. La France guerrière. Paris : Toquet, 1827. P. $23-29$.

55. Richebourg É. Histoire d'un avare, d'un enfant et d'un chien. Paris : E. Dentu, 1878. $307 \mathrm{p}$. 
56. Molènes $P$. de. Les souffrances d'un houzard // Molènes P. de. Les caprices d'un régulier; Les souffrances d'un houzard; Le soldat en 1709. Paris Hachette, 1863. P. 241-330.

57. Wolf A. La gloriole: mémoires d'un parisien. Paris : Victor-Havard, 1888. 338 p.

58. Murger H. Propos de ville et propos de théâtre. Paris : Michel Lévy, 1853. 95 p.

59. Audebrand Ph. Romanciers et viveurs du XIX-e siècle. Paris : Calmann-Lévy, 1904. $346 \mathrm{p}$.

60. Montagne É. Le manteau d'Arlequin. Paris : Librairie internationale, A. Lacroix, 1866. $302 \mathrm{p}$.

61. Féval P. La Bande Cadet. Paris : E. Dentu, 1875. 380 p.

62. Sivry L. de. Rome et l'Italie méridionale, promenades et pèlerinages suivis d'une description sommaire de la Sicile. Paris : Belin-Leprieur, 1843. 368 p.

63. Royer J.-M. Le Prince Jacques et le Roy François: l'an I de la cohabitation. Paris : Le Pré aux Clercs, 1987. 295 p.

Bérézina Among Full Synonyms-Proper Names with the Meaning of a Catastrophic Failure: Linguistic and Cultural Aspects

Vestnik Tomskogo gosudarstvennogo universiteta. Filologiya - Tomsk State University Journal of Philology. 2020. 64. 93-108. DOI: 10.17223/19986645/64/7

Vitaliy I. Pinkovskiy, North-Eastern State University (Magadan, Russian Federation). E-mail: alennart@mail.ru

Keywords: Bérézina, Waterloo, Leipzig, Sedan, absolutely synonymous proper names, dominant word of synonym cluster, concept, images, beliefs and prejudices of national consciousness.

The article examines a group of French precedent proper names with the meaning of a catastrophic failure (Bérézina, Waterloo, Leipzig, Sedan) and raises the question of the phenomenon of the word Bérézina, about its more frequent (in comparison with other members of the synonym series) use in different domains of culture. The author believes that the study of such issues can reveal a great deal both in the mechanism of the language functioning and in the national psychology of the people using this language in a certain historical period. About 400 texts of various types (publicistic, memoir, documentary and artistic) created in the 19th21 st centuries were used as the material for the study. Finding out the conditions of "competition" between the synonyms, the author considers the words in the context of the advantage of their internal forms, phonic and articulation merits, derivational potential, compatibility, and their propensity to metaphorical and other semantic transfers. It has been determined that, in this case, logical and linguistic factors do not influence the primary provision of this or that word in a synonymic series (otherwise, the words Leipzig and Sedan would have the greatest chance of indicating a major defeat). The conceptual analysis (which considers the historical, psychological, and cultural context of the existence of words) leads to the conclusion that the foundations of the phenomenon under study are in the figurative nature and in the field of interpretation of synonymous concepts. In particular, Bérézina is the only word that raises direct body sensations in the collective consciousness, among which chill is the most frequent. This is in line with the mass ideas of the 19th-century French people about Russia as a country reminding of an icy desert. Furthermore, Bérézina acts as an embodiment of natural destructive forces; and to suffer defeat from such is not shameful. The circumstances mentioned above explain the advantages of the proper name Bérézina over other members of the synonymous series: in comparison with Waterloo, it is a concept perceived to a greater extent by feelings than by reason, and, in comparison with Sedan, the mention of the Bérézina crossing does not raise the feeling of the bitterness of national humiliation. Distancing from the empirical reality connected with the word Bérézina, the author comes to the following conclusions. Among the full synonyms - proper names, the most often and variously used words: (a) have a high figurative potential; (b) do not "conflict" with mental stereotypes of the national consciousness; (c) do not evoke traumatic associations; (d) can be used in the personal and 
household sphere as the phenomena filling this sphere are diverse and repeated over and over again, which allows a continuous updating of the arsenal of word meanings and addition of some new senses to them.

\section{References}

1. Sklyarenko, O.N. (n.d.) O leksiko-semanticheskikh osobennostyakh sobstvennykh imen [On the Lexical and Semantic Features of Proper Names]. [Online] Available from: http://dspace.onu.edu.ua:8080/bitstream/123456789/4559/1/170-181.pdf.

2. Nakhimova, E.A. (2011) Pretsedentnye onimy v sovremennoy rossiyskoy massovoy kommunikatsii: teoriya i metodika kognitivno-diskursivnogo issledovaniya [Precedent Onyms in Modern Russian Mass Communication: Theory and Methodology of Cognitive-Discursive Research]. Yekaterinburg: Ural State Pedagogical University.

3. Merzlyakova, A.V. (2015) Semanticheskiy potentsial toponimov sovremennogo frantsuzskogo yazyka [The Semantic Potential of Toponyms of the Modern French Language]. Philology Cand. Diss. Nizhniy Novgorod.

4. Kudryavtseva, A.A. (2011) Peculiarity of Compatibility of the Mythic Proper Names Which Converted to Appellative Names. Uchenye zapiski Zabaykal'skogo gosudarstvennogo gumanitarno-pedagogicheskogo universiteta im. N. G. Chernyshevskogo-Scholarly Notes of Transbaikal State University. 2 (37). pp. 67-70. (In Russian).

5. Kudryavtseva, A.A. (2013) Osnovnye tipy onimov, sposobnykh perekhodit' v imena naritsatel'nye [The Main Types of Onyms That Can Become Common Nouns]. Izvestiya Volgogradskogo gosudarstvennogo pedagogicheskogo universiteta - Ivzestia of the Volgograd State Pedagogical University. 4 (79). pp. 65-68.

6. Caradec, F. \& Pouy, J.-B. (2009) Dictionnaire de Français argotique et populaire. Paris: Larousse.

7. Reverso: dictionnaire. [Online] Available from: http://dictionnaire.reverso.net/francaisdefinition/beresina.

8. Sirinelli, J.-F. (ed.) (2006) Dictionnaire de l'histoire de France. Paris: Larousse.

9. Boissière, P. (1862) Dictionnaire analogique de la langue française: répertoire complet des mots par les idées et les idées par les mots. Paris: A. Boyer.

10. Grineva, E.F. \& Gromova, T.N. (1997) Slovar' razgovornoy leksiki frantsuzskogo yazyka [Dictionary of French Colloquial Vocabulary]. Moscow: Tsitadel'.

11. Shumakova, A.N. (2015) The Peculiarities of Using Culture-Specific Lexis in the Modern Press (As Exemplified by Toponyms Related to Napoleon's Campaigns). Vestnik Moskovskogo gosudarstvennogo lingvisticheskogo universiteta - Vestnik of Moscow State Linguistic University. 9 (720). pp. 74-83. (In Russian).

12. Postnikova, A.A. (2014) Precedents of the Napoleonic Era in Communicative Memory of Contemporary France: From "Austerlitz" to "Bistro". Politicheskaya lingvistikaPolitical Linguistics. 3 (49). pp. 216-223. (In Russian).

13. Caraco, A. (1975) Ma confession. Lausanne: L'age d'homme.

14. Anon. (1814) L'agonie d'un sénateur, et son amende honorable à la nation française. Paris: Chez les marchands de nouveautés.

15. Berthezène, A. (1892) Waterloo. Paris: E. Leroux.

16. Chambrun, J.-D.-A.-P. (1872) Fragments politiques. Paris: Garnier frères.

17. Déchalotte, J.-B. (1858) La France et l'Angleterre d'autrefois et d'aujourd'hui. Paris: Blot.

18. Mague, A. (1890) Dédicace à Madame la Duchesse d'Uzès. Le Proscrit de Jersey. État actuel de la France, impression de cet état en Europe. Paris: Charles.

19. Teste, L. (1910) Anatomie de la République (1870-1910). Paris: Librairie du XX-e siècle.

20. Barrès, M. (1897) Le roman de l'énergie national. Les déracinés. Paris: E. Fasquelle.

21. Bussard. S. (2015) La Bérésina des républicains du Congrès. [Online] Available from: https://blogs.letemps.ch/etats-unis/2015/03/04/la-beresina-des-republicains-du-congres/. 
22. Neumann, L. (2015) Un “Waterloo” de la responsabilité politique. [Online] Available from: http://www.lepoint.fr/invites-du-point/laurent-neumann/neumann-un-waterloo-de-laresponsabilite-politique-13-06-2015-1936119_2449.php.

23. Lemov, A.V. (2015) Whether Doublets-Synonyms Are Identical or Not. Istoricheskaya i sotsial'no-obrazovatel'naya mysl' - Historical and Social Educational Ideas. 7 (3). pp. 211-213.

24. Hervieu, P. (1895) L'armature. Paris: A. Lemerre.

25. Ghil, R. (1938) Euvres complètes. T. 3. Paris: A. Messein. pp. 195-252.

26. Bremond, H. (1926) La poésie pure. Paris: B. Grasset.

27. Le Robert. (2011) Le Robert pratique: dictionnaire d'apprentissage de la langue française. Paris: Le Robert.

28. Stepanov, Yu.S. (2013) Frantsuzskaya stilistika (v sravnenii s russkoy) [French Stylistics (In Comparison with Russian)]. Moscow: Knizhnyy dom "Librokom".

29. Hubbard, G.-A. (1873) Le budget des 3 monarchies et le budget de la République. Paris: Société d'instruction républicaine.

30. Dentu, E. (ed.) (1875) Le dernier Empire. Paris: E. Dentu.

31. Bigot, Ch. (1883) Le petit Français. Paris: E. Weill et G. Maurice.

32. Delafosse, J. (1876) Le procès du 4 septembre. Paris: E. Lachaud et Cie.

33. Gerbet, Ph. (1871) Un mot sur les catastrophes des armées françaises en 1870-1871. Arbois: Javel.

34. Largeaud, J.-M. (2006) Napoléon et Waterloo: la défaite glorieuse de 1815 à nos jours. Paris: Boutique de l'histoire.

35. Hugo, V. (1881) Les misérables. 5 vol. 2-e partie. Cosette. Paris: Hachette.

36. Delavigne, C. (1818) Trois Messéniennes, élégies sur les malheurs de la France. Paris: Ladvocat. pp. 5-11.

37. Clairville. (1840) Le retour de Sainte-Hélène: à-propos national en un acte. Paris: Tresse.

38. Desjardins, abbé. (1866) Roncevaux. Gloire aux vaincus! Melun: A. Hérisé.

39. Houssaye, H. (1907) La garde meurt et ne se rend pas: histoire d'un mot historique. Paris: Perrin.

40. Fontaubert, É. de. (1869) Chants et chansons de Pourceaugnac II. Limoges: Vve H. Ducourtieux. pp. 27-28.

41. Sérieyx, W. (1931) Cambronne. Paris: J. Tallandier.

42. Belmontet, L. (1853) Poésie de l'Empire français. Paris: Impr. Impériale. pp. 139144.

43. Cain, J. \& François, M. (1935) Exposition des 318 lettres de Napoléon à Marie-Louise récemment acquises par le Gouvernement français. Paris: Bibliothèque national.

44. Napoléon, I. (1829) Mémoires de Napoléon, écrits sous sa dictée à Sainte-Hélène, par un de ses valets de chambre. Paris: Philippe.

45. Pierron, É. (1889) Comment s'est formé le génie militaire de Napoléon I? Paris:

L. Baudoin.

46. Zamoyski, A. (2012) 1812: Napoleons Feldzug in Russland. München: C.H. Beck.

47. Tolstoy, L.N. (1984) Voyna i mir [War and Peace]. In: Sobr. soch.: 12 t. [Collected Works]. Vol. 6. Moscow: Pravda.

48. Neuville, A. (1837) Euvres d'un désœuvré. Chaumont: Mion. p. 47.

49. Delandine de Saint-Esprit, J. (1843) Histoire de l'Empire, 1804-1814. Paris: Mallet et Cie.

50. Gautier, Th. (1913) Emaux et camées. Paris: G. Crès et Cie. pp. 81-87.

51. Puech, L. (1877) Le despote: abrégé historique du règne de Napoléon I. Castres:

A. Fraysse.

52. de Vogüe, E.-M. (1893) Discours. In: Banquet franco-russe du 26 octobre 1893. Paris: Colin. pp. 14-15.

53. Anon. (1859) Les prisonniers français en Russie (1813-1814). [S.1.].

54. Nerval, G. de. (1827) La France guerrière. Paris: Toquet. pp. 23-29. 
55. Richebourg, É. (1878) Histoire d'un avare, d'un enfant et d'un chien. Paris: E. Dentu.

56. Molènes, P. de. (1863) Les caprices d'un régulier; Les souffrances d'un houzard; Le soldat en 1709. Paris: Hachette. pp. 241-330.

57. Wolf, A. (1888) La gloriole: mémoires d'un parisien. Paris: Victor-Havard.

58. Murger, H. (1853) Propos de ville et propos de théâtre. Paris: Michel Lévy.

59. Audebrand, Ph. (1904) Romanciers et viveurs du XIX-e siècle. Paris: Calmann-Lévy.

60. Montagne, É. (1866) Le manteau d'Arlequin. Paris: Librairie internationale, A. Lacroix.

61. Féval, P. (1875) La Bande Cadet. Paris: E. Dentu.

62. Sivry, L. de. (1843) Rome et l'Italie méridionale, promenades et pèlerinages suivis d'une description sommaire de la Sicile. Paris: Belin-Leprieur.

63. Royer, J.-M. (1987) Le Prince Jacques et le Roy François: l'an I de la cohabitation. Paris: Le Pré aux Clercs. 